\title{
In Vitro Propagation and Mutagenesis of Jatropha Curcas
}

\author{
M.G.EL-Torky ${ }^{1}$, H.M.EL-Naggar ${ }^{1}$ and N.A. El-Shanhorey ${ }^{2}$, A.A. yousef ${ }^{2}$
}

\begin{abstract}
This study was carried out in the Tissue Culture Laboratory, Department of Flowers, Ornamental Plants and Landscape Gardens, Faculty of Agriculture (ElShatby), Alexandria University, Egypt during the period from 2012 to 2015 to establish an efficient and reliable protocol for in vitro propagation and improve of Jatropha curcas. Seeds of Jatropha were effectiveness of mutation induction by different ways. Planted on Murashige and Skoog media (MS), using different combinations Indol acetic acid (IAA) at 0,1 and $2 \mathrm{mg} / \mathrm{l}$ and benzyl adenine (BA) at 0, 1, 2 and $3 \mathrm{mg} / \mathrm{l}$ of kintin (Kin) at $2.0 \mathrm{mg} / \mathrm{l}$ and for shoot regeneration. While the media used for rooting was amendmented with different (IAA) at 0,1 and $2 \mathrm{mg} / \mathrm{l}$ and indol butyric acid (IBA) at $0,1,2$ and $3 \mathrm{mg} / \mathrm{l}$. Oil was extracted from seeds and callus formed on MS medium containing combinations of $\mathrm{BA}$ at $0.5,1$ and $1.5 \mathrm{mg} / \mathrm{l}$, (NAA) at 1, 2 and $3 \mathrm{mg} / \mathrm{l}$ and 2,4-dichlorophenoxyacetic acide (2,4-D) at $0.5 \mathrm{mg} / \mathrm{l}$.
\end{abstract}

Regenerated rooted plants were then treated by colchicines or glufosinate ammonium at 1, 2, 3 and $4 \mathrm{mg} / \mathrm{l}$ for each. The best medium for shoot regeneration was MS amended with BA at 2 and $3 \mathrm{mg} / \mathrm{l}$ and IAA at 1mg/l, while the best rooting medium was MS amended with IAA at $2 \mathrm{mg} / \mathrm{l}$ and IBA at1 and $2 \mathrm{mg} / \mathrm{l}$. For obtaining the highest percentage of oil content from callus, medium at $0.5 \mathrm{mg} / \mathrm{l}$ BA combined with $2 \mathrm{mg} / \mathrm{l} \mathrm{NAA}$ and $0.5 \mathrm{mg} / \mathrm{l} 2,4-\mathrm{D}$ gave the best results. For the induction of genetic variation glyphosinate ammonium to be added at $3 \mathrm{mg} / \mathrm{l}$, while colchicines had at all concatenation no effect on cell division of Jatropha curcas plant.

Key words: In vitro culture - Jatropha curcas - micro propagation - Colchicine - Glufosinate ammonium RABD.

\section{INTRODUCTION}

Jatropha curcas,Linn belongs to the family Euphorbiaceae . Jatropha comprises over 175 native species occurring in South to Central America, Asia and Africa, each cell of Jatropha has 22 chromosomes (Mukherjee et al, 2011 and Kumar and Reddy, 2012). It is an oil bearing tree or shrub that grows in almost all subtropical and tropical areas. The most important aspect of this species is its large potential for biofuel production. Owing to high oil content of the seed, rapid growth and stiffness of the plant, Jatropha curcas is a

DOI: 10.21608/asejaiqjsae.2021.159990

${ }^{1}$ Floriculture,Ornamental Horticulture and Landscape Gardening,

Fac.Agric., Alex.Univ.,Egypt.

${ }^{2}$ Department of Botanical Garden (Antoniades),

Horticultural Research Institute, (A.R.C), Alex, Egypt.

Received February 19, 2021, Accepted March 25, 2021 sustainable source of second generation biodiesel feedstock species and the overall supply can be increased with different propagation technologies. In addition, the plant can grow in drought, and also in different types of soil as reported by (Mukherjee et al, 2011; Nahar 2011 and Kumar and Reddy, 2012).

Moreover, it can be conveniently propagated from seeds, stem cuttings, grafting as well as by tissue culture, Jatropha curcas seeds contain about 30-35 percent of non-edible oil, an efficient substitutes for diesel engines, and can live for about 50 years as reported by (Henning, 2002; Dagar et al, 2006 and Deng et al. ,2010).

Most important Jatropha oil is an environmentally safe, cost-effective renewable source of nonconventional energy and a promising substitute for diesel, kerosene and other fuel oils, various parts of Jatropha are used medicinally viz., latex, oil, twigs, wood and leaves are all reportedly used externally for healing wounds, to stop bleeding, and to treat skin disease and rheumatism as reported by Achten et al., 2008 and Henning, 2010.

Jatropha micropropagation by seeds as an alternative to the conventional methods for vegetative propagation, is becoming important owing to certain advantages such as increasing multiplication rates and the attention of plant material free of viruses and other pathogens (Nhut et al., 2006).

Micropropagation (or in vitro propagation) is the most common term used for clonal, true-to-type propagation of plants by a variety of tissue, cell and organ culture methods, it implies the aseptic culture of small sections (i.e., explants) of tissues and organs, in closed vessels with defined culture media and under controlled environmental conditions, micropropagation, in addition to genetic engineering, is at present the most commercially efficient and practically-oriented plant biotechnology, resulting in rapid generation of a large number of clonal plants of many plant species, which are in many cases also virus- or other pathogen-free, it is now the technical link in the generation of transgenic plants and somatically-bred plants through tissue culture (Loberant and Altman, 2010).

Colchicine is a natural alkaloid with an antimitotic activity, obtained from the plant Colchicum autumnale 
L.plant (Emsweller, 1988; Van Tuyl et al., 1990). When colchicine is present in a cell that is undergoing mitotic division, the chromosomes split at all points except the centromere, causing duplication in the number of chromosomes per cell. The main action of the colchicine is to prevent the formation of a spindle so the anaphase movement of the chromosomes does not take place and the cell fails to divide, when the daughter chromosomes finally divide, they are all included in one cell and the chromosome number is doubled to be effective, colchicine must be present in the cell when the chromosomes divide. Colchicine is very harmful to humans and in some cases shows undesirable mutagentic activity on plants, colchicine is effective in doubling the chromosome number (Van Tuyl et al., 1990).

Glufosinate ammonium is a broad spectrum herbicide used for the control of many weed species, as well as a desiccant for certain crops. Its primary mode of action is through the inhibition of glutamine synthetases (Lea and Ridley ,1989), which leads to a build-up of ammonium in the cell (Wendler et al., 1990) and disruptions in photorespiratory pathways, inhibiting photosynthesis (Lacuesta et al., 1992; Merkel et al., 2004). Translocation of glufosinate ammonium after absorption is highly variable (and species dependent) and is often limited by its fast action at the sites of contact resulting in rapid phytotoxicity (necrosis), though small rates of transportation, through phloem, to roots and floral parts have been reported (Pline et al.,1999 and Skora et al., 2000). The half-life of glufosinate in bare topsoil is fairly short (approximately 1 week); however small amounts can still be detected in spring water run-off following snow melt (Siimes et al., 2006). The main action of phosphinothricin is a glutamine synthetase inhibitor that binds to the glutamate site. Glufosinate-treated plants die due to a buildup of ammonia and corresponding decrease in $\mathrm{pH}$ in the thylakoid lumen, leading to the uncoupling of photophosphorylation. The uncoupling of photophosphorylation causes the production of reactive oxygen species, lipid peroxidation and membrane destruction (Carpenter and Boutin , 2010).

The main aim of this study was to establish a protocol for micro propagation of Jatropha using different concentrations of auxins and cytokinins, as well as studying the effect of different doses of chemical mutagens on in vitro generated plants of Jatropha curcas. The possibility of the emergence of genetic mutations and variations on the plant is also addressed.

\section{MATERIALS AND METHODS}

The present investigation was carried out at the Tissue Culture Laboratory in the Flowers, Ornamental Plants and landscape Gardens Department, Faculty of Agriculture (El-shatby), Alexandria University, during the period from 2012 to 2015 . The experiment consisted of two stages, the first stage was the micropropagation of Jatropha curcas, the second stage was the induction of mutations using two chemical mutagen colchicine and glufosinate ammonium.

Plant material and explants sterilization: Fresh seeds (after removing pod coat) of Jatropha curcas were obtained from the trees grown in Antoniadis Gardens, Alex., Egypt, seeds were washed under running tap water for $20 \mathrm{~min}$, then dipped in Clorox bleach 5\% for 20 min then in mercuric chloride $0.1 \%$ for one min then in ethanol $75 \%$ for one min then washed three times with sterile distilled water. The seeds were aseptically placed in jars containing $20 \mathrm{ml}$ of culture media, each jar containing one seed.

Preparation and sterilization of culture media: The $\mathrm{pH}$ of all media used was adjusted at $5.8 \pm 0.1$ using 1.0 $\mathrm{M}$ of $\mathrm{HCl}$ and /or $1.0 \mathrm{M}$ of $\mathrm{NaOH}$, agar was added after adjusting the $\mathrm{pH}$, then, MS medium contained in addition to the prescribed salts and vitamins, 30g/l sucrose and $7 \mathrm{~g} / \mathrm{l}$ agar were autoclaved at $121^{\circ} \mathrm{C}$ for 20 minutes under (15psi) $1.05 \mathrm{~kg} / \mathrm{cm}^{2}$ pressure (Murashige and Skooge,1962), medium was left to cool and stored at $25 \pm 2{ }^{\circ} \mathrm{C}$ for one week before being used in order to exclude contaminated jars. All equipments were autoclaved for $30 \mathrm{~min}$ at $121^{\circ} \mathrm{C}(15 \mathrm{psi})$. Glass jar of $9 \mathrm{~cm}$ height $\mathrm{x} 5 \mathrm{~cm}$ diameter with their poly propylene caps, were used during multiplication, establishment and rooting stages.

\section{(A) In vitro propagation:}

\section{1-Shoot regeneration}

To determine the appropriate micropropagation condition or media for Jatropha micropropagation, the initiation stage was conducted as follows: Seeds were cultured on MS basal supplemented $2.0 \mathrm{mg} / \mathrm{l}$ Kin with different concentrations of BA $(0,1,2$ and $3 \mathrm{mg} / \mathrm{l})$ combined with different concentrations of IAA $(0,1$ and $2 \mathrm{mg} / \mathrm{l})$. One seed was cultured in each jar in culture room under controlled conditions $(25 \pm$ $2{ }^{\circ} \mathrm{C}, 16 / 8$ light/dark cycle) Two weeks after seed germination cotyledons were excised and placed on a new media with the same constitutes as mentioned above, for two weeks.

\section{2-Rooting stage}

After two weeks the regenerated shoots were transferred on MS medium with $0.0,1$ and $2 \mathrm{mg} / \mathrm{l}$ IAA combined with $0.0,1,2$ and $3 \mathrm{mg} / \mathrm{l}$ IBA. The experiment consisted of 12 treatments and every 
treatment contained 5 replicates, and each replicate comprised one regenerated shoot.

\section{3-Callus stage}

Leaf segments were cultured on (MS) media supplemented $2,4 \mathrm{D}$ at $0.5 \mathrm{mg} / \mathrm{l}$ with different concentrations of BA at $(0.5,1$ and $1.5 \mathrm{mg} / \mathrm{l})$ combined with NAA at $(1,2,3 \mathrm{mg} / \mathrm{l})$, every Leaf segment was placed in a jar for two weeks under controlled conditions at temperature $\pm 25^{\circ} \mathrm{C}$ and light/dark cycle $16 / 8 \mathrm{hrs}$ at the culture room.

\section{The following morphological characters were measured:}

- Percentage of successful seed germination $\%$.

- Number of shoots.

- Shoots length $(\mathrm{cm})$.

- Fresh weight of regenerated shoot (g).

- The time for roots induction (day).

- Number of roots per regenerated shoot.

- Root length after two week (cm).

\section{Statistical analysis}

The obtained data were statistically analyzed as Completely Randomized Design (CRD) in a factorial design (Steel and Torrie, 1980). Comparisons among means were made using the least significant differences test (L.S.D) . Data were analyzed using SAS institute program multiple comparisons method (Tukey, 1994).

- Shoot regeneration: Number of treatments $=4$ concentration of BA X 3 concentration of IAA $=12$ treatment (Number of replicates $=5$ replicates).

Total number of jar $=12$ treatment $X 5$ replicates $=$ 60 jars / experiment.

- Rooting: Number of treatments $=4$ concentration of IBA X 3 concentration of IAA $=12$ treatment (Number of replicates $=5$ replicates).

Total number of jar $=12$ treatment $X 5$ replicates $=$ 60 jars / experiment.

\section{- Callus induction in Jatropha curcas}

The obtained data were statistically analyzed as completely randomized design (CRD) design according to the SAS program, SAS Institute (Snedecor and Cochran, 1967) Comparisons among means were made using the least significant differences test (L.S.D) according to (SAS Institute, 2002) at 0.05 level of probability.

\section{(B) The use of chemical mutagens:}

\section{- The use of colchicine}

Small pieces of fresh root tip specimens of Jatropha plants were removed and fixed by immersing them immediately in F4G1 (4 Formalin :1glutaraldehyde) in phosphate buffer solution $\mathrm{pH}=7.2$ at $4^{\circ} \mathrm{C}$ for 3 hours.

Specimens were then post fixed in $2 \%$ OsO4 (Osmium Tetroxide solution) in the same buffer at $4^{\circ} \mathrm{C}$ for 2 hours. Sample (5) were washed in the buffer and dehydrated at $4^{\circ} \mathrm{C}$ through agraded series of acetone .Then embedded in resin to polymerize then samples were cut into sections about 90 angstrom in thickness. Sections place were on grid cobber. Stained by uranyl acetate $5 \mathrm{~min}$, then lead citrate for $2 \mathrm{~min}$, the cells was tested under transmission electron microscopy (TEM) ( Dalton, 1955 and Sarah. et al, 1957).

\section{- The use of glufosinate ammonium}

Glufosinate ammonium was applied through bacterial filters and after sterilizing the media before solidifying at temperature about $50^{\circ} \mathrm{C}$ and were added at the following concentrations of 1,2,3 and $4 \mathrm{mg} / \mathrm{l}$, the rooted regeneration shoots were then transferred on glufosinate ammonium media, placed in the growth chamber for two weeks.

DNA extraction and purification for the RAPD analysis

Total DNA was extracted from plants using gene jet plant genomic DNA purification mini kit K0791 Thermo Scientific, $100 \mathrm{mg}$ of young leaves taken from each plant and thoroughly were washed with water then ethylene and then milled under liquid nitrogen. The DNA was extracted using plant tissue purification kit according to many-factures instruction. DNA extracted was tested using gel electrophoresis at $1.2 \%$ agarose gel. The DNA was stored at $-20^{\circ} \mathrm{C}$ for further work (Cato and Richardson, 1996).

Seven primers of 17 nucleotides each, except for OPD-05 primer 10 nucleotides (Table1) were used for RAPD analysis for the 10 tissue culture treatments of Jatropha curcas. Each PCR amplification was performed twice for each primer to ensure their reproducibility in a total volume of $27 \mu$ l containing 12 $\mu \mathrm{l}$ Master mix (Thermo Scientific)] (dream taq TM red PCR master mix (DNA polymerase + optimized red buffer $+\mathrm{Mg} \mathrm{Cl}_{2}$ and dNTPs.) $+3 \mu$ the purified DNA + $3 \mu \mathrm{l}$ primer $+9 \mu \mathrm{l}$ water]. For the RAPD analysis ,the PCR amplification was performed with initial denaturation at $94{ }^{\circ} \mathrm{C}$ for $1 \mathrm{~min}$, followed by $30-35$ cycles of denaturation at $94^{\circ} \mathrm{C}$ for $1 \mathrm{~min}$, annealing at 50 ${ }^{\circ} \mathrm{C}$ for 1 min according to different primer used and extension at $72^{\circ} \mathrm{C}$ for $1 \mathrm{~min}$. The final extension at $72{ }^{\circ} \mathrm{C}$ for 5 min. period of extension was $1.48 \mathrm{~h}$ (Dzialuk et al., 2011).

The PCR amplified products were subjected to electrophoresis in a $1.5 \%$ agarose gel containing ethidiumbromide (at $4 \mu \mathrm{l}$ ) in (1X) TBE buffer for 40 min using cleaver submarine electrophoresis unit .Gene 
ruler 100pb plus DNA ladder from (Thermo Scientific) as was used to identify the DNA amplified band size (Brody and Kern, 2004).

The cluster analysis and polymorphic tree were done by PyELph software system for gel image analysis and phylogenetics version 2.6.5 (Pavel and Vasile , 2012).

Table 1. ISSR primers used in finger-print - PCR reaction

\begin{tabular}{lll}
\hline $\begin{array}{c}\text { No. of } \\
\text { primer }\end{array}$ & $\begin{array}{c}\text { Primer } \\
\text { name }\end{array}$ & \multicolumn{1}{c}{ Sequence 5' to3' } \\
\hline P1 & 823 & TCTCTCTCTCTCTCTCC \\
P2 & 810 & GAGAGAGAGAGAGGAT \\
P3 & 826 & ACACACACACACACACC \\
P4 & 828 & TGTGTGTGTGTGTGTGA \\
P5 & 818 & CACACACACACACACAG \\
P6 & 808 & AGAGAGAGAGAGAGAGC \\
P7 & OPD- & GCGGACTGA \\
& 05 & \\
\hline
\end{tabular}

\section{Statistical analysis}

The obtained data were statistically analyzed as completely randomized design (CRD) design according to the SAS program, SAS Institute (SAS Institute, 2002) Comparisons among means were made using the least significant differences test (L.S.D) according to (Snedecor and Cochran, 1967) at 0.05 level of probability.

\section{RESULTS AND DISCUSSION}

\section{In vitro propagation}

\section{Shoot regeneration}

Data presented in table (2) and photo $(1,2)$ showed that the best result for the percentage of successful seed germination was found when IAA was used at $1 \mathrm{mg} / 1$ $(72.50 \%)$ or when BA was applied at $3 \mathrm{mg} / \mathrm{l}(80.00 \%)$. The best results for number of days for shoot formation and the number of shoots were obtained with IAA at $2 \mathrm{mg} / 1$ (11.40 and1.90) or when BA was applied at 3 $\mathrm{mg} / \mathrm{l}$ (11.66 and 2.06), the highest shoot length was recorded when IAA was used at $1 \mathrm{mg} / 1(4.5 \mathrm{~cm})$ or when BA was used at $0 \mathrm{mg} / \mathrm{l}(4.3 \mathrm{~cm})$.

Data presented in table (2) showed that the best result for the number of leaves was detected when IAA was used at $1 \mathrm{mg} / \mathrm{l}$ (3.9 leaves) or when BA was applied at $3 \mathrm{mg} / \mathrm{l}$ (3.8 leaves), while the best leaf area was obtained at $1 \mathrm{mg} / \mathrm{l}$ IAA $\left(0.032 \mathrm{~cm}^{2}\right)$ or when BA was applied at $2 \mathrm{mg} / \mathrm{l}\left(0.029 \mathrm{~cm}^{2}\right)$ photo (3) , the best result for chlorophyll content was detected when IAA was used at $2 \mathrm{mg} / \mathrm{l}$ (37.53 SPAD unit) or when BA was applied at 3mg/l (36.71SPAD unit).

For fresh weight best result was recorded when IAA was applied at $2 \mathrm{mg} / \mathrm{l}(1.27 \mathrm{~g})$ or when BA was used at1 $\mathrm{mg} / \mathrm{l}(1.03 \mathrm{~g})$. While the best result for dry weight was recorded when IAA was applied at $2 \mathrm{mg} / \mathrm{l}(0.10 \mathrm{~g})$ or when BA was used at $0 \mathrm{mg} / \mathrm{l}(0.11 \mathrm{~g})$.

Table 2. Effects of IAA and BA on shoot regeneration of Jatropha curcas cultured on MS media

\begin{tabular}{|c|c|c|c|c|c|c|c|c|c|c|}
\hline 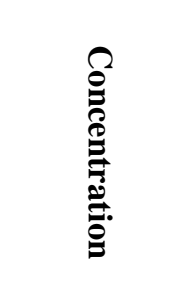 & & 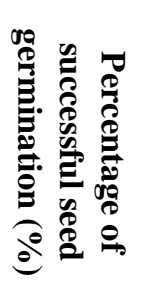 & 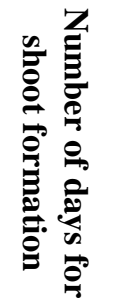 & 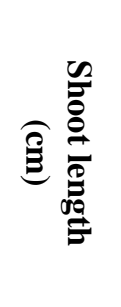 & 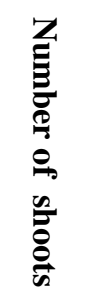 & 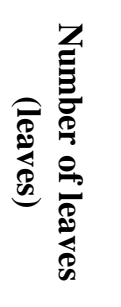 & 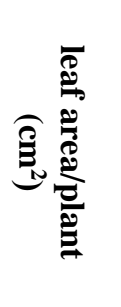 & 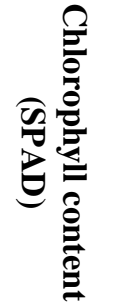 & 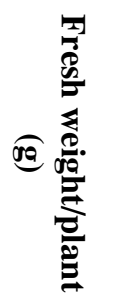 & 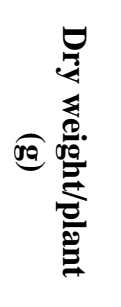 \\
\hline \multirow{3}{*}{$\mathrm{IAA}(\mathrm{mg} / \mathrm{l})$} & 0 & $61.25^{\mathrm{c}}$ & $10.90^{\mathrm{a}}$ & $4.12^{\mathrm{ab}}$ & $1.30^{\mathrm{b}}$ & $3.15^{\mathrm{ab}}$ & $0.019^{b}$ & $24.02^{\mathrm{c}}$ & $0.534^{\mathrm{c}}$ & $0.065^{\mathrm{a}}$ \\
\hline & 1 & $72.50^{\mathrm{a}}$ & $10.90^{\mathrm{a}}$ & $4.50^{\mathrm{a}}$ & $1.65^{\mathrm{ab}}$ & $3.90^{\mathrm{a}}$ & $0.032^{\mathrm{a}}$ & $30.41^{\mathrm{b}}$ & $0.799^{\mathrm{b}}$ & $0.067^{\mathrm{a}}$ \\
\hline & 2 & $70.00^{b}$ & $11.40^{\mathrm{a}}$ & $3.72^{b}$ & $1.90^{\mathrm{a}}$ & $2.80^{\mathrm{b}}$ & $0.021^{\mathrm{b}}$ & $37.53^{\mathrm{a}}$ & $1.278^{\mathrm{a}}$ & $0.102^{\mathrm{a}}$ \\
\hline \multirow{2}{*}{\multicolumn{2}{|c|}{ L.S.D (0.05) }} & 1.01 & 0.76 & 0.78 & 0.43 & 0.75 & 0.009 & 4.70 & 0.250 & 0.069 \\
\hline & & $55.00^{\mathrm{d}}$ & $10.60^{b}$ & $4.30^{\mathrm{a}}$ & $1.40^{\mathrm{b}}$ & $3.33^{\mathrm{ab}}$ & $0.030^{\mathrm{a}}$ & $30.66^{b}$ & $0.666^{\mathrm{b}}$ & $0.109^{a}$ \\
\hline \multirow{3}{*}{ BA (mg/l) } & 1 & $71.60^{\mathrm{b}}$ & $11.06^{\mathrm{ab}}$ & $4.26^{\mathrm{a}}$ & $1.53^{\mathrm{a}}$ & $3.46^{\mathrm{ab}}$ & $0.023^{\mathrm{ab}}$ & $23.98^{\mathrm{c}}$ & $1.037^{\mathrm{a}}$ & $0.074^{\mathrm{a}}$ \\
\hline & 2 & $65.00^{c}$ & $10.93^{\mathrm{ab}}$ & $4.20^{\mathrm{a}}$ & $1.46^{b}$ & $2.60^{\mathrm{b}}$ & $0.029^{\mathrm{a}}$ & $31.26^{\mathrm{ab}}$ & $0.944^{\mathrm{ab}}$ & $0.064^{\mathrm{a}}$ \\
\hline & 3 & $80.00^{\mathrm{a}}$ & $11.66^{\mathrm{a}}$ & $3.70^{\mathrm{a}}$ & $2.06^{\mathrm{a}}$ & $3.80^{\mathrm{a}}$ & $0.015^{\mathrm{b}}$ & $36.72^{a}$ & $0.834^{\mathrm{ab}}$ & $0.066^{\mathrm{a}}$ \\
\hline L.S.D (0.05) & & 1.30 & 0.97 & 0.62 & 0.55 & 0.95 & 0.012 & 5.98 & 0.310 & 0.882 \\
\hline
\end{tabular}

Columns with the same letter(s) are not significantly different from each other at 5\% level of probability. 


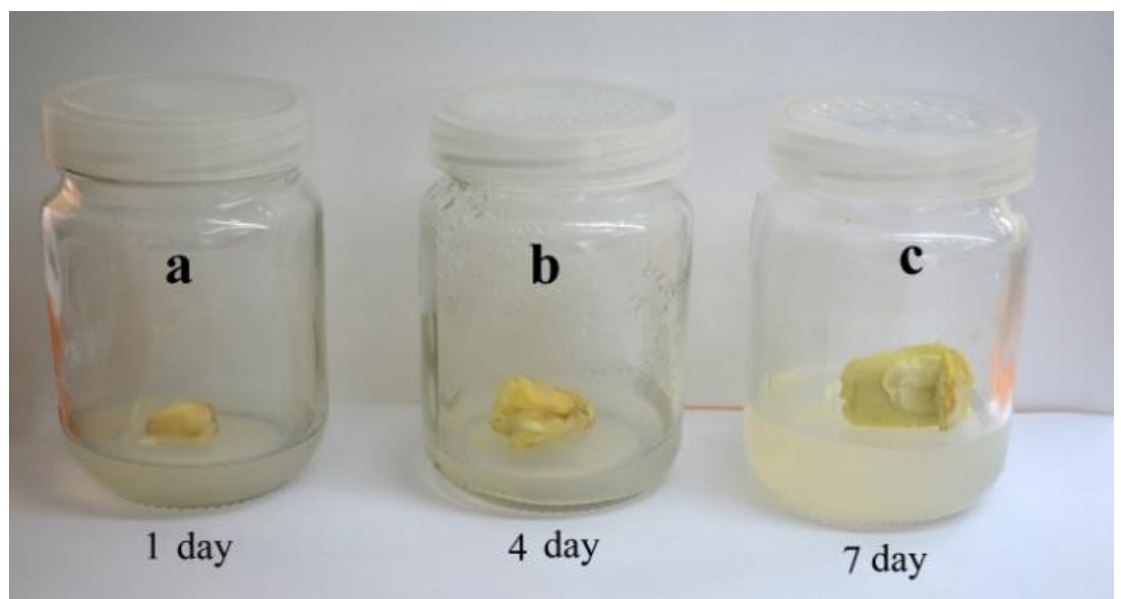

Photo 1. Photo showing stages of germination in Jatropha curcas L. under the effect of BA and IAA at different concentrations in in vitro culture

(a): seed 1day old showing the begging of germination.

(b): seed 4days old showing the begging of germination.

(c): seed 7days old showing the begging of germination.
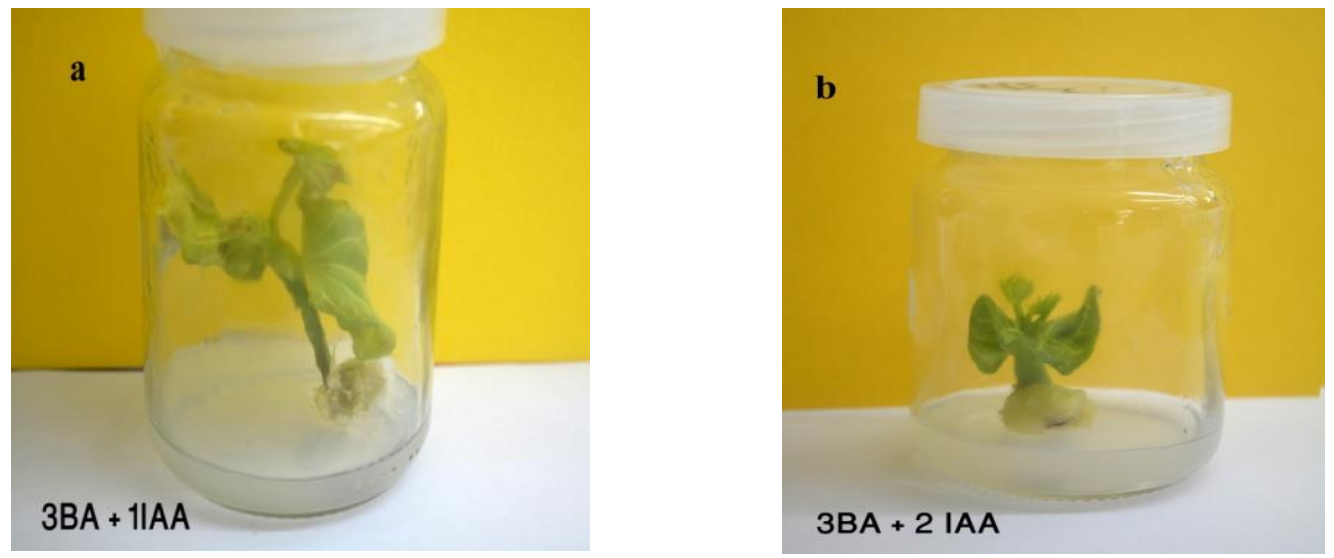

Photo 2. photo showing shoot length (cm) of Jatropha curcas under the effect of BA and IAA at different concentrations in In vitro culture

(a): Shows the effect of BA at $3 \mathrm{mg} / \mathrm{l}$ with $\mathrm{IAA}$ at $1 \mathrm{mg} / \mathrm{l}$ on shoot length.

(b): Shows the effect of BA at $3 \mathrm{mg} / \mathrm{l}$ with IAA at $2 \mathrm{mg} / \mathrm{l}$ on shoot length. 

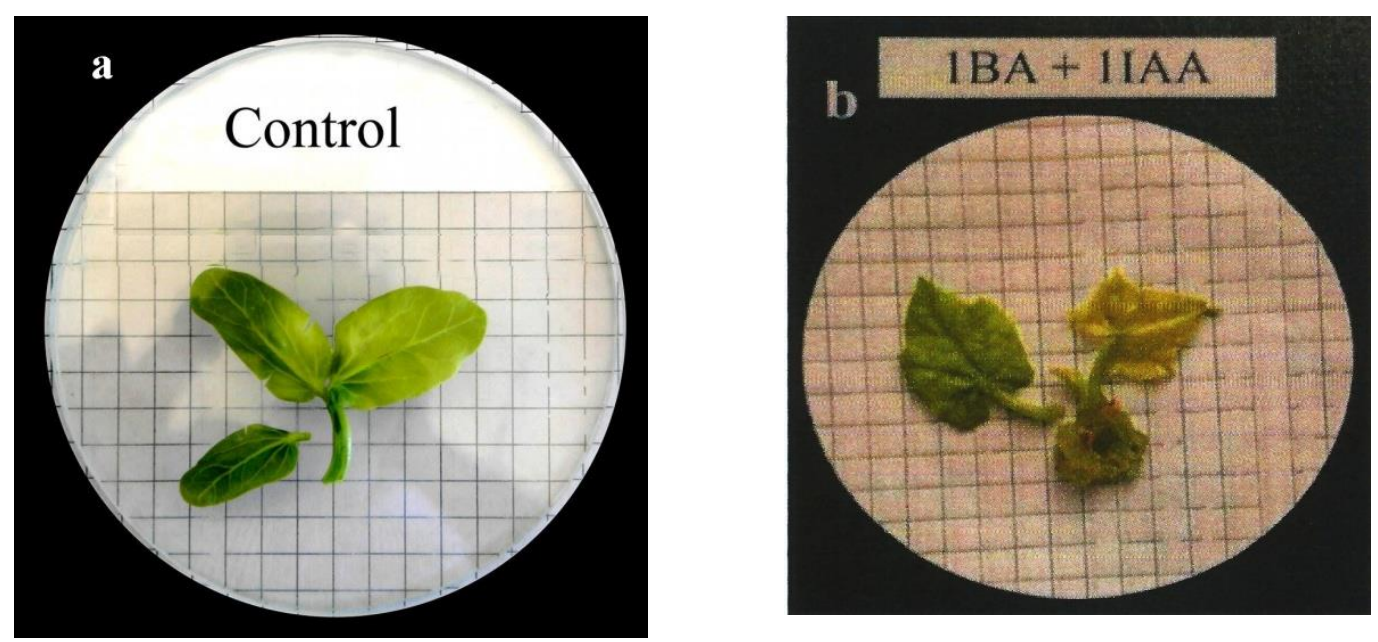

Photo 3. Photo showing leaf area/plant $\left(\mathrm{cm}^{2}\right)$ of Jatropha curcas under the effect of BA and IAA at different concentrations in in vitro culture

(a): Shows the leaf area at control.

(b): Shows effect of BA at $1 \mathrm{mg} / \mathrm{l}$ with IAA at $1 \mathrm{mg} / \mathrm{l}$ on the leaf area.

Data in table (3) regarding the interaction between IAA and BA showed that the best result of percentage of successful seed germination and shoot length were found when IAA was used at $1 \mathrm{mg} / \mathrm{l}$ combined with BA at $3 \mathrm{mg} / 1(95 \%, 5.5 \mathrm{~cm})$ respectively. The best result for number of days for shoot formation was detected when IAA at $1 \mathrm{mg} / \mathrm{l}$ and BA at 0mg/l (10 days) were applied, while the number of shoots was found when IAA was used at $2 \mathrm{mg} / \mathrm{l}$ combined with BA at 3mg/l (3 shoots). This results were in agreement with Shrivastava and Banerjee (2009) who found that the high concentration of the BA with low concentration of auxins produced an increase in shoot formation of Jatropha curcas .BA is considered to be one of the most useful cytokinins for achieving the multiplication and micropropagation ,there are several reasons for preferred use of BA, one of the reasons is that it can be autoclaved without losing its activity (Stfaan ,1994).However some other workers have reported a combination of cytokinin and auxin to be fruitful for axillary and apical bud sprouting in different species (Joshi and Dhar, 2003, Dhar and Joshi 2005,Baker,1999).

While data in Table (3) showed that the best result of the number of leaves was found when IAA was used at $1 \mathrm{mg} / \mathrm{l}$ combined with BA at $3 \mathrm{mg} / \mathrm{l}$ (5leaves). The best result of the leaf area and dry weight were found when IAA was used at $2 \mathrm{mg} / \mathrm{l}$ combined with BA at $0 \mathrm{mg} / 1\left(0.0530 \mathrm{~cm}^{2}\right.$ and $\left.0.192 \mathrm{~g}\right)$ respectively. The best result for chlorophyll content was detected when IAA at $2 \mathrm{mg} / \mathrm{l}$ and BA at 2mg/l (42.14 SPAD unit) was applied, the fresh weight increased when IAA was used at $1 \mathrm{mg} / \mathrm{l}$ combined with BA at $1 \mathrm{mg} / \mathrm{l}(1.44 \mathrm{~g})$. Those results were in agreement with Shrivastava and Banerjee (2009) on Jatropha curcas. Similar trend was observed for chlorophyll contents in C. forskohlii by Sahai and Shahzad (2013). Cytokines stimulate the movement and accumulation of food in leaves and increase weight, in addition to cells weight related to wall cellulose and water, that observed increase in fresh weight of stem in Avene sativadue treated with BA (Rahdari et al., 2013 and Naji et al., 2015).

\section{Rooting stage}

Data presented in table (4) showed that the best result for the percentage of survival rate after rooting was found when IAA was used at $1 \mathrm{mg} / 1(95.00 \%)$, the best result for the time for root induction and root length were found when IAA at $0 \mathrm{mg} / \mathrm{l}$ (11. 50 days and $4.70 \mathrm{~cm}$ ) respectively. While the best result for number of roots per regenerated shoot was recorded when IAA at $2 \mathrm{mg} / \mathrm{l}$ (4.4 roots). When IBA was used at $1 \mathrm{mg} / 1$ gave the best percentage of survival rate after rooting (96.66\%), while the best result for the time for root induction and the root length were found when IBA was amended at 2mg/l (11 days and $6.6 \mathrm{~cm}$ ) respectively, while the best result for number of roots per regenerated shoot was recorded when IBA was used at $3 \mathrm{mg} / \mathrm{l}$ (4.1 roots). 
Table 3. Effects of interaction between IAA and BA on shoot regeneration of Jatropha curcas in culture on MS media

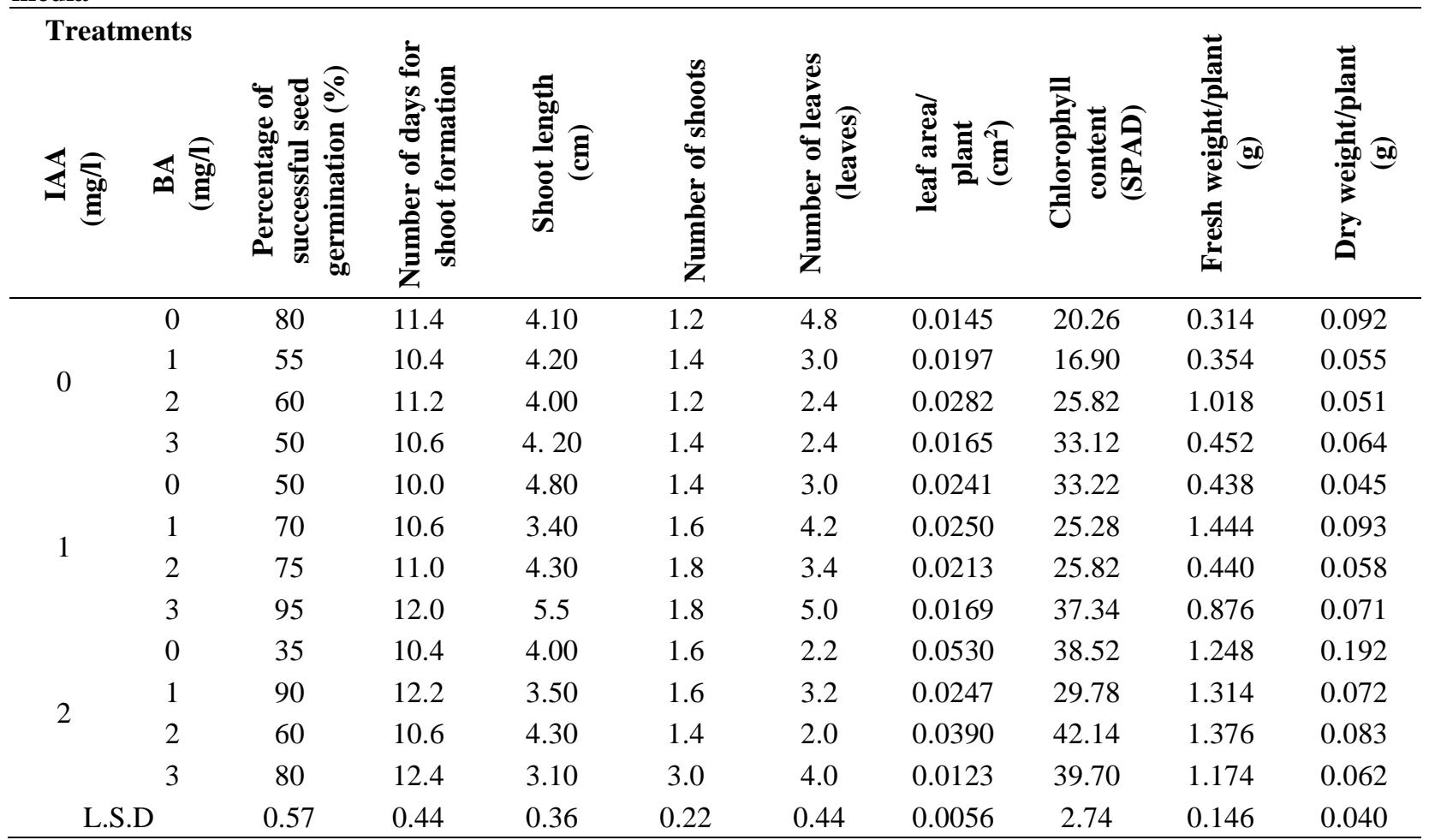

L.S.D at 0.05 level of probability.

Table 4. Effects of IBA and IAA on the rooting from regenerated shoots of Jatropha curcas cultured on MS media

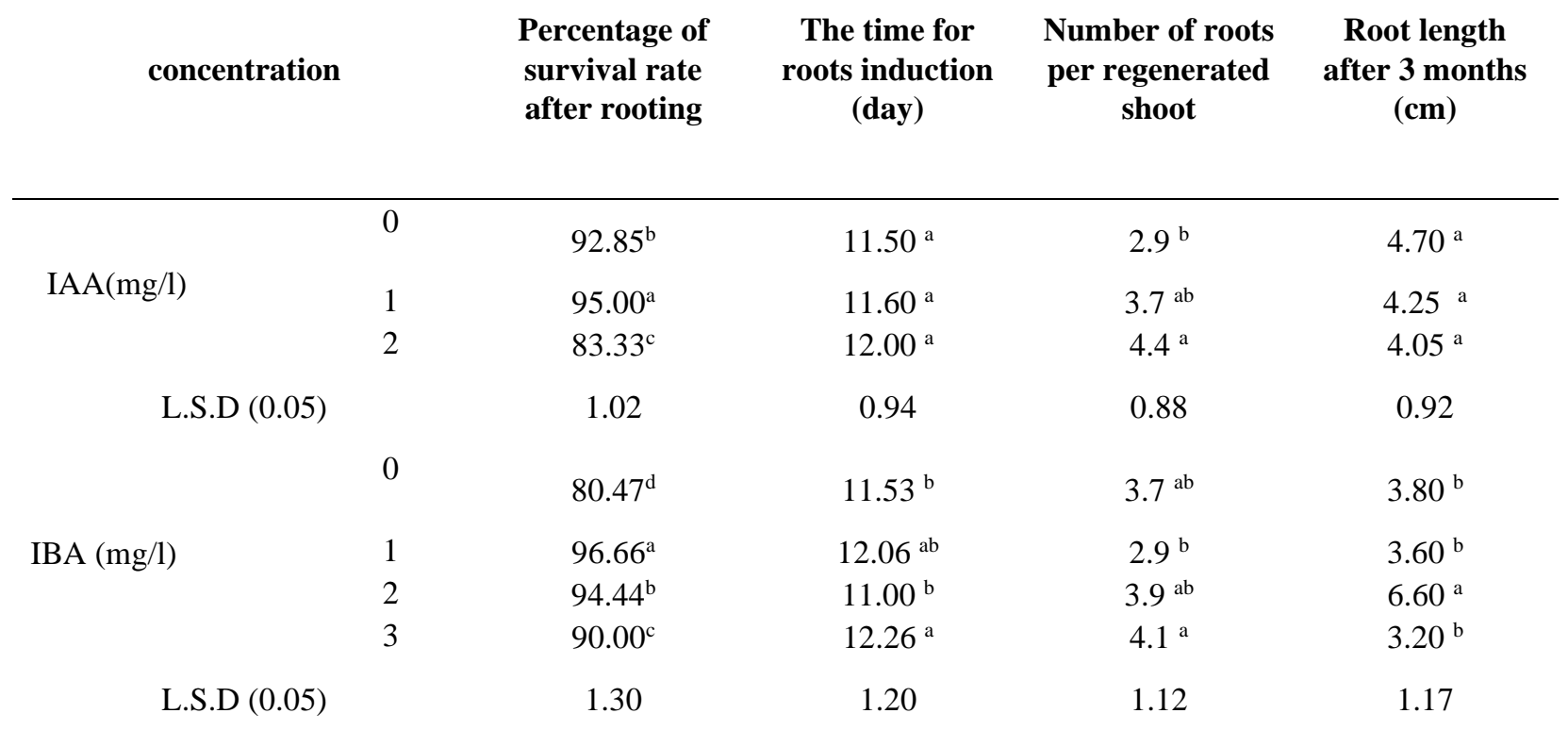

Columns with the same letter(s) are not significantly different from each other at $5 \%$ level of probability. 
Data in table (5), regarding the interaction between IAA and IBA, showed that the best results of the percentage of survival rate after rooting was found when IAA was combined with IBA at all concentrations (100 $\%$ ) except the $0 \mathrm{mg} / \mathrm{l}$ (IAA or BA) (control) treatment, while the best result of number of days for root induction was found when IAA was used at $1 \mathrm{mg} / \mathrm{l}$ combined with IBA at $2 \mathrm{mg} / \mathrm{l}$ (10.6 days). The best result of the number of roots per regenerated shoot and root length were $(4.6$ roots and $7.00 \mathrm{~cm}$ ) respectively if $1 \mathrm{AA}$ at $2 \mathrm{mg} / \mathrm{l}$ was combined with IBA at $2 \mathrm{mg} / \mathrm{l}$.
These results were probably due to the effect of auxin on adventitious root induction and elongation that is highly dependent on the plant type (Nandagopal and Kumari, 2007) Shrivastava and Banerjee (2009) found that the high concentration of IBA produced a clear increase in the root number and root length of Jatropha.

Auxins are considered to be causative agent for root differentiation, the role of auxins in root development is well established and reviewed (Scott, 1972).

Table 5. Effects of interaction between IAA and IBA on shoot regeneration of Jatropha curcas in culture on MS media

\begin{tabular}{cccccc}
\hline $\begin{array}{c}\text { Treatments } \\
\text { IAA } \\
(\mathbf{m g} / \mathbf{l})\end{array}$ & $\begin{array}{c}\text { IBA } \\
(\mathbf{m g} / \mathbf{l})\end{array}$ & $\begin{array}{c}\text { Percentage of } \\
\text { survival rate after } \\
\text { rooting }\end{array}$ & $\begin{array}{c}\text { The time for roots } \\
\text { induction(day) }\end{array}$ & $\begin{array}{c}\text { Number of roots } \\
\text { per regenerated } \\
\text { shoot }\end{array}$ & $\begin{array}{c}\text { Root length } \\
\text { after 3month } \\
\text { (cm) }\end{array}$ \\
\hline & 0 & 90 & 12.8 & 3.2 & 3.00 \\
0 & 1 & 90 & 11.0 & 2.4 & 5.20 \\
& 2 & 83 & 11.4 & 3.2 & 6.20 \\
& 3 & 70 & 10.8 & 4.2 & 4.40 \\
& 0 & 80 & 11.2 & 2.6 & 4.20 \\
1 & 1 & 100 & 10.8 & 4.2 & 3.00 \\
& 2 & 100 & 10.6 & 4.0 & 3.00 \\
& 3 & 100 & 14.0 & 4.0 & 4.20 \\
& 0 & 71 & 10.8 & 5.6 & 2.60 \\
& 1 & 100 & 14.2 & 3.4 & 7.00 \\
& 2 & 100 & 11.0 & 4.6 & 2.40 \\
& 3 & 100 & 12.0 & 4.0 & 0.5385 \\
\hline
\end{tabular}

L.S.D at 0.05 level of probability.
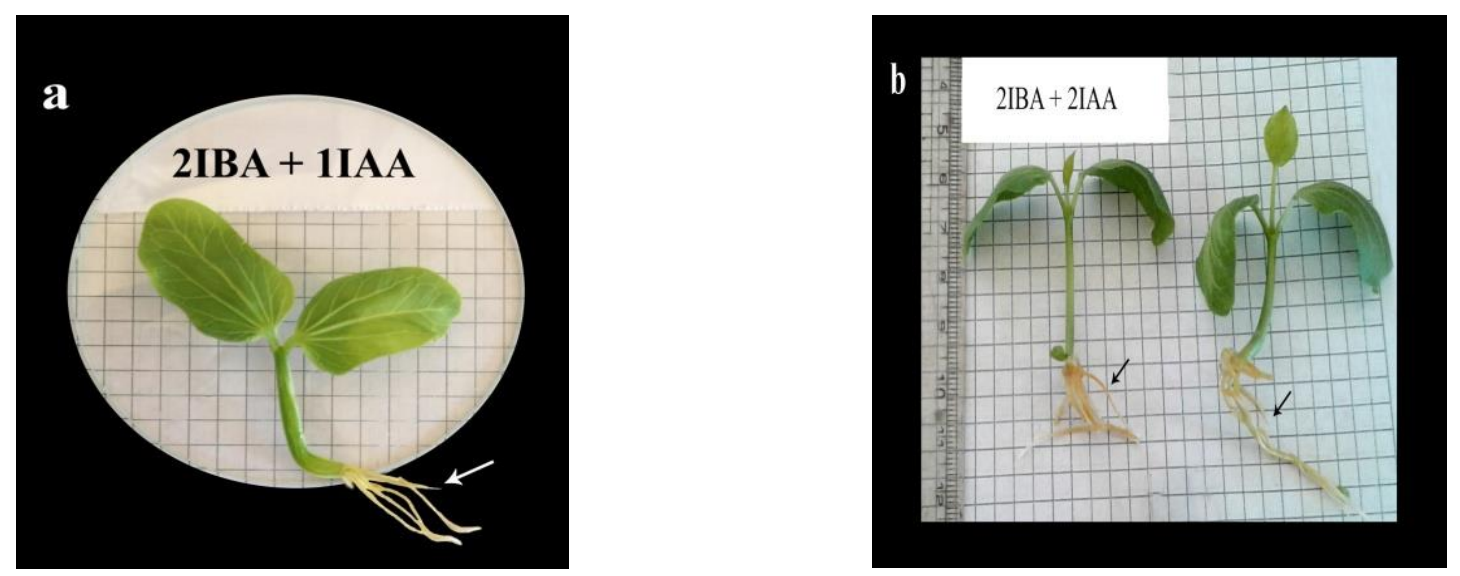

Photo 5. Photo showing root number and roots length $(\mathrm{cm})$ in Jatropha curcas under the effect of IBA and IAA at different concentrations in vitro culture

(a): Shows effect of IBA at $2 \mathrm{mg} / \mathrm{l}$ with IAA at $1 \mathrm{mg} / \mathrm{l}$ on root number.

(b): Shows effect of IBA at $2 \mathrm{mg} / \mathrm{l}$ with IAA at $2 \mathrm{mg} / \mathrm{l}$ on root length. 


\section{Use of the chemical mutagen.}

The effect of colchicines on the root tip cells in Jatropha curcas .

Colchicine is a poisonous medicinal chemical and has been used in plant breeding work to produce doubling in the number of chromosomes in cells known as polyploidy (Derman and Emsweller 1961). In our present study it was found that colchicine at concentrations from 1 to $4 \mathrm{mg} / \mathrm{l}$ has no effect on cell division of Jatropha curcas plant which appears under transmission electron microscope (TEM) photo (8), which showed that all the root tip cells of Jatropha curcas treated with colchicine were formed normally in all examined cells. These results are in agreement with Derman and Emsweller (1961) who mentioned that the colchicine if applied in diluted concentrations will be ineffective also. They also mentioned that the type of plant and the thickness of the tissues and cell wall may affect the efficiency of the colchicine. The woody plants are not affective as the herbaceous plants when treated with colchicine.

\section{The effect of glufosinate ammonium on in vitro} cultures of Jatropha curcas.

Since the glyphosate mode of action is the inhabitation of the enzyme 5-enolpyruvyl shikimate 3-P synthesis which controls the aromatic acid synthesis in plants ,also it causes the methylatian and the damage of the plant DNA therefore the morphologycal or cytological detection for any mutation or change will not be sufficient as reported by Cavas and Konen (2007), that is why PCR was used to detect any variation between Jatropha plants treated with 5 different concentrations of gluphosinate DNA was extracted from the control the plants treated with the gluphosinate (Photo 9).

RAPD is a multiplex marker system that conventionally uses single primer PCR to amplify random DNA fragments (Kumar et al.,2009). The fragment sizes of DNA produced range from 150 to 1200 bps. The number and size of DNA fragments produced from the RAPD varied among different glufosinate ammonium treatments. A number of unique bands of DNA fragments were found when comparing the control or wild type and $3 \mathrm{mg} / \mathrm{l}$ glufosinate ammonium treatment where three bands were missing in the $3 \mathrm{mg} / \mathrm{l}$ treatment (Photo 10,11).

A unique band appeared between 100 and $200 \mathrm{bp}$ in the $2 \mathrm{mg} / \mathrm{l}$ glufosinate treatment. Also two missing bands can be distinguished in the 2 and $4 \mathrm{mg} / \mathrm{l}$ treatment compared to the control (Photo 10) and (Table6).

The polymorphic tree (Fig 1) showed that there are two main clusters the $3 \mathrm{mg} / \mathrm{l}$ glyfosinate cluster and the rest of the treatments make the second cluster which means that the glufosinate used at $3 \mathrm{mg} / \mathrm{l}$ gave the highest genetic variation compared to the control. This is in agreement with Cavas and Konen (2007) who mentioned that low concentration of glufosinate could cause DNA methylation and DNA fragmentationas well as DNA damage . on other hand, the 1,2 and $4 \mathrm{mg} / \mathrm{l}$ made subcluster related to the control with the less genetic variation than the $3 \mathrm{mg} / \mathrm{l}$ gluphosinate. This result is also in agreement with Buchanan et al.(2000) who mentioned that the small concentration of glufosinate will not cause any mutations or genetic variations to the treated organisms.
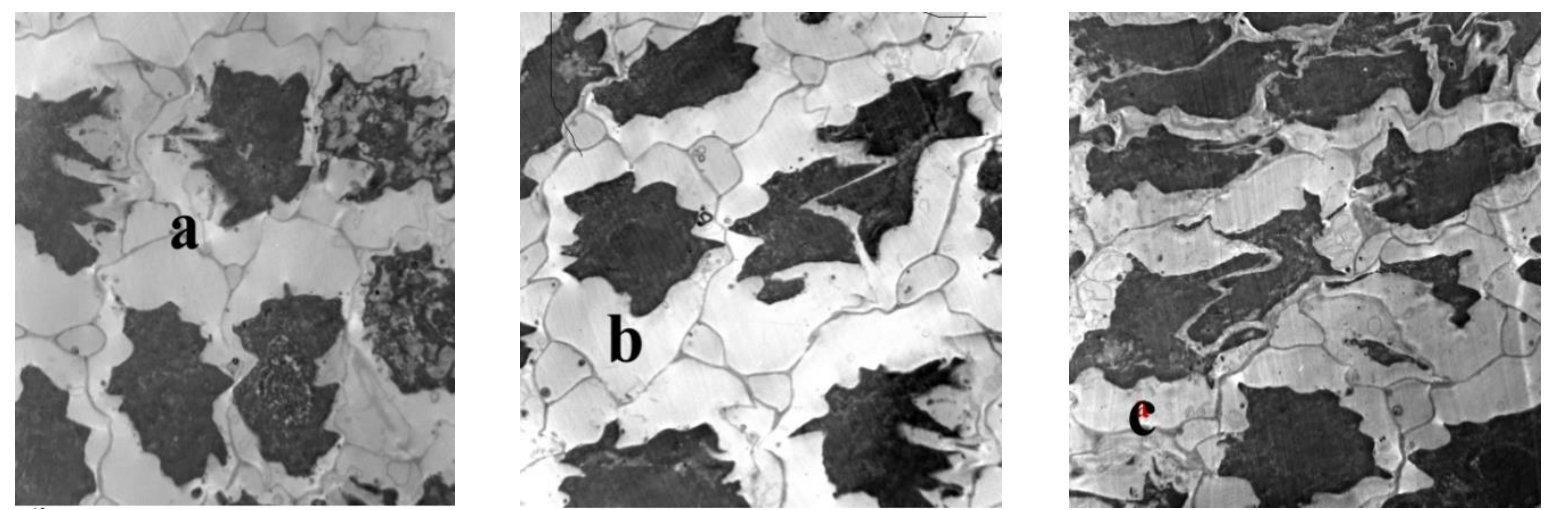

Photo 8. The root tip cells of Jatropha curcas treated with colchicines and examined under electron microscope showing normal division

(a) : T.S of normal cell without division.

(b) : T.S of normal cell division.

(c) : L.S of normal cell division . 
A big contradict in the effect of gluphosinate in causing mutation or its DNA damaging effect yielded cartiavers of results in relation to the tested dose and application method and organism (Rank et al., 1993) and Sivikova and Dianovsky, 2006 ).

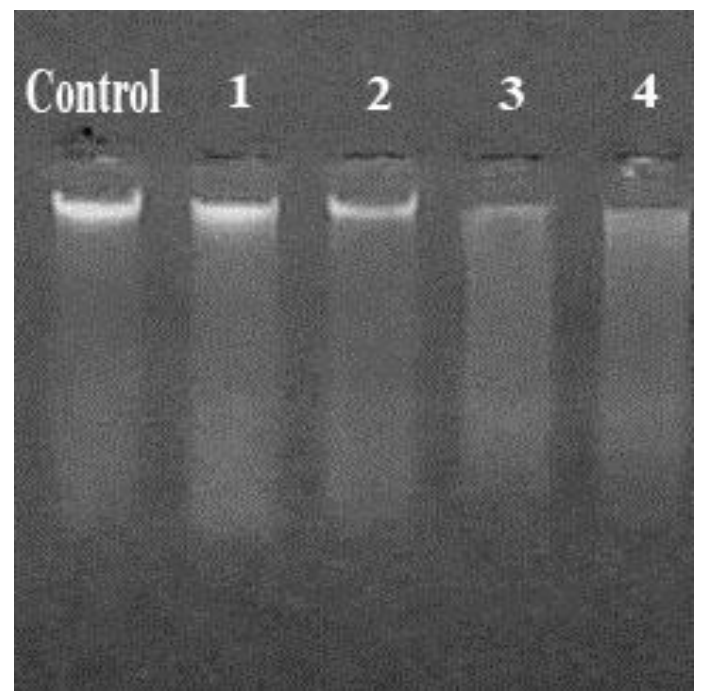

Photo 9. Gel electrophoresis of the DNA extracted from leaf samples of Jatropha plant treated with five different concentrations of glufosinate ammonium $(0,1,2,3$ and $4 \mathrm{mg} / \mathrm{l})$
These results showed that glufosinate ammonium with moderate concentrations $(3 \mathrm{mg} / \mathrm{l})$ gave the highest variation compared to the control and the rest of treatments.

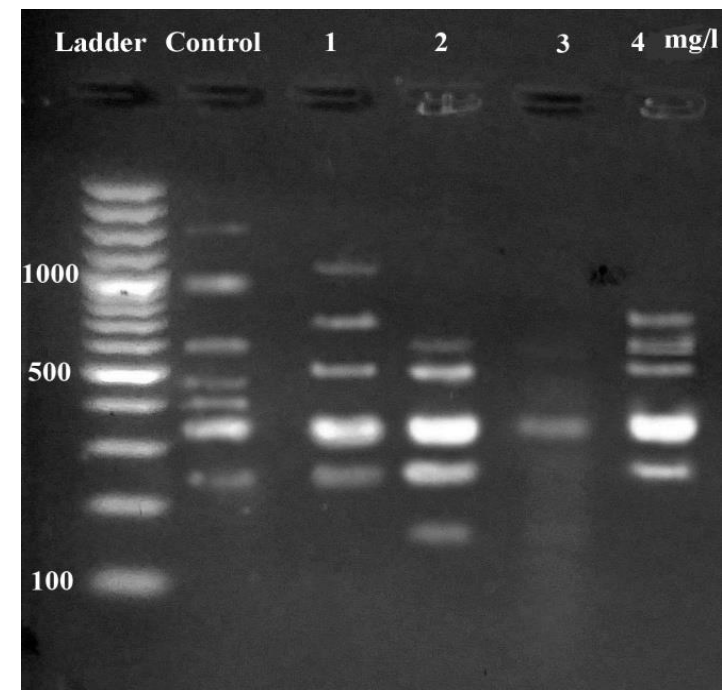

Photo 10. Gel electrophoresis of the PCR reaction showing the effect of five different concentrations of glufosinate ammonium $(0,1,2,3$ and $4 \mathrm{mg} / 1$ on Jatropha curcas using 7 primers, showing amplified bands ranging from 150 and $1200 \mathrm{bp}$

Table 6. Number of bands and number of polymorphic bands detected by 7 different primers for the finger print of Jatropha treated with different concentrations of glufosinate ammonium Number of bands (fragments)

\begin{tabular}{|c|c|c|c|c|c|}
\hline $\begin{array}{l}\text { Treatment } \\
(\mathrm{mg} / \mathrm{l})\end{array}$ & $\mathbf{0}$ & 1 & 2 & 3 & 4 \\
\hline Primer1 (823) & 4 & 2 & 0 & 0 & 3 \\
\hline Primer2 (810) & 0 & 2 & 0 & 0 & 0 \\
\hline Primer3 (826) & 2 & 3 & 2 & 1 & 2 \\
\hline Primer4 (828) & 0 & 0 & 3 & 1 & 4 \\
\hline Primer5 (818) & 0 & 0 & 0 & 0 & 0 \\
\hline Primer6 (808) & 0 & 1 & 0 & 1 & 2 \\
\hline Primer7 (OPD-05) & 0 & 1 & 2 & 0 & 0 \\
\hline Total number of bands & 6 & 9 & 7 & 3 & 8 \\
\hline Number of polymorphic bands & 7 & 5 & 5 & 1 & 5 \\
\hline
\end{tabular}



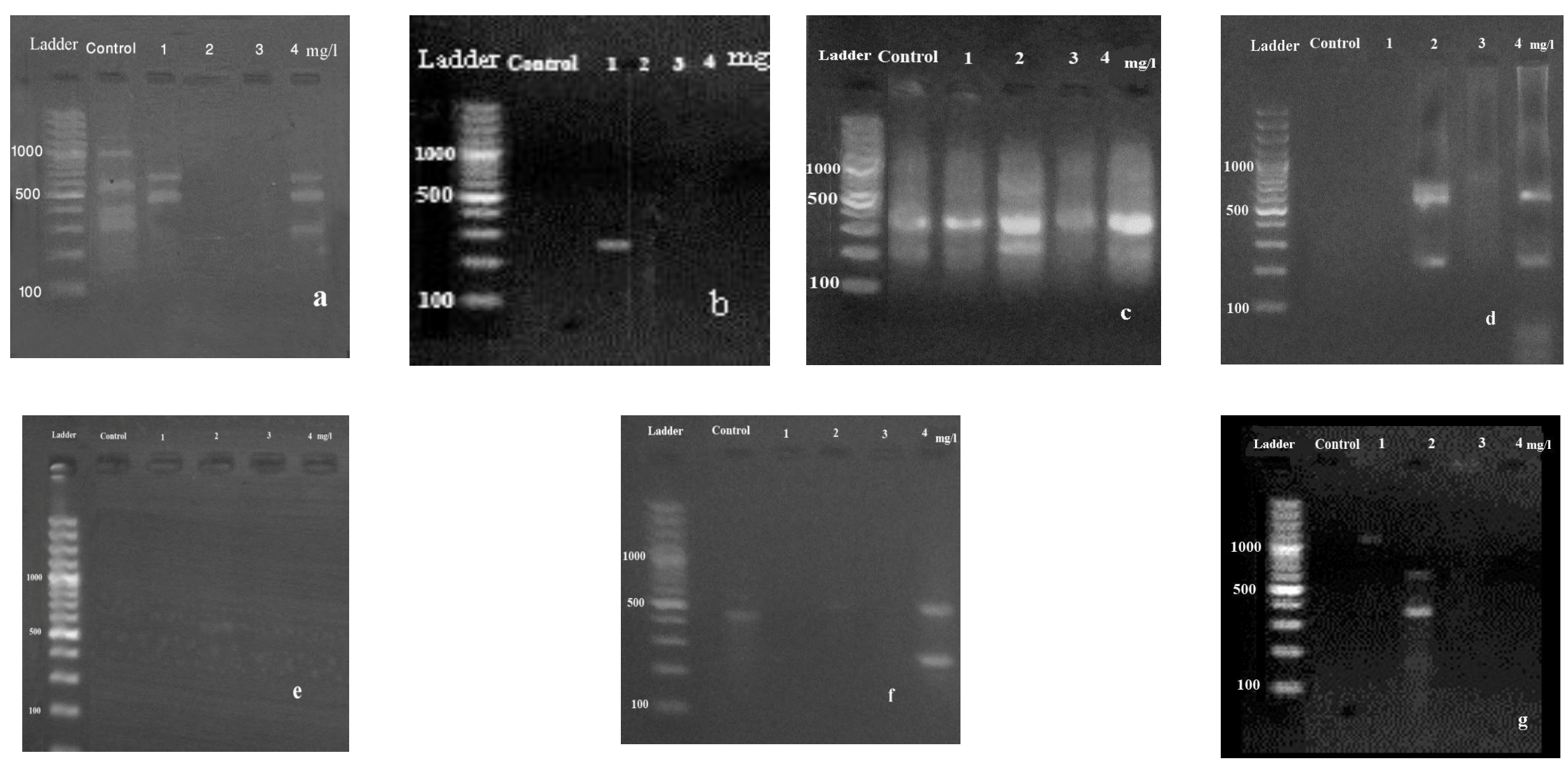

Photo 11. Gel electrophoresis of finger print-PCR reaction of the seven primers a,823;b, 810; c,826;d, 828;e, 818;f, 808 and $\mathrm{g}, \mathrm{OPD}-05$, lanes from 1 to 5 indicate treatments of glufosinate ammonium at $0,1,2,3$ and $4 \mathrm{mg} / \mathrm{l}$ respectively on Jatropha curcas 


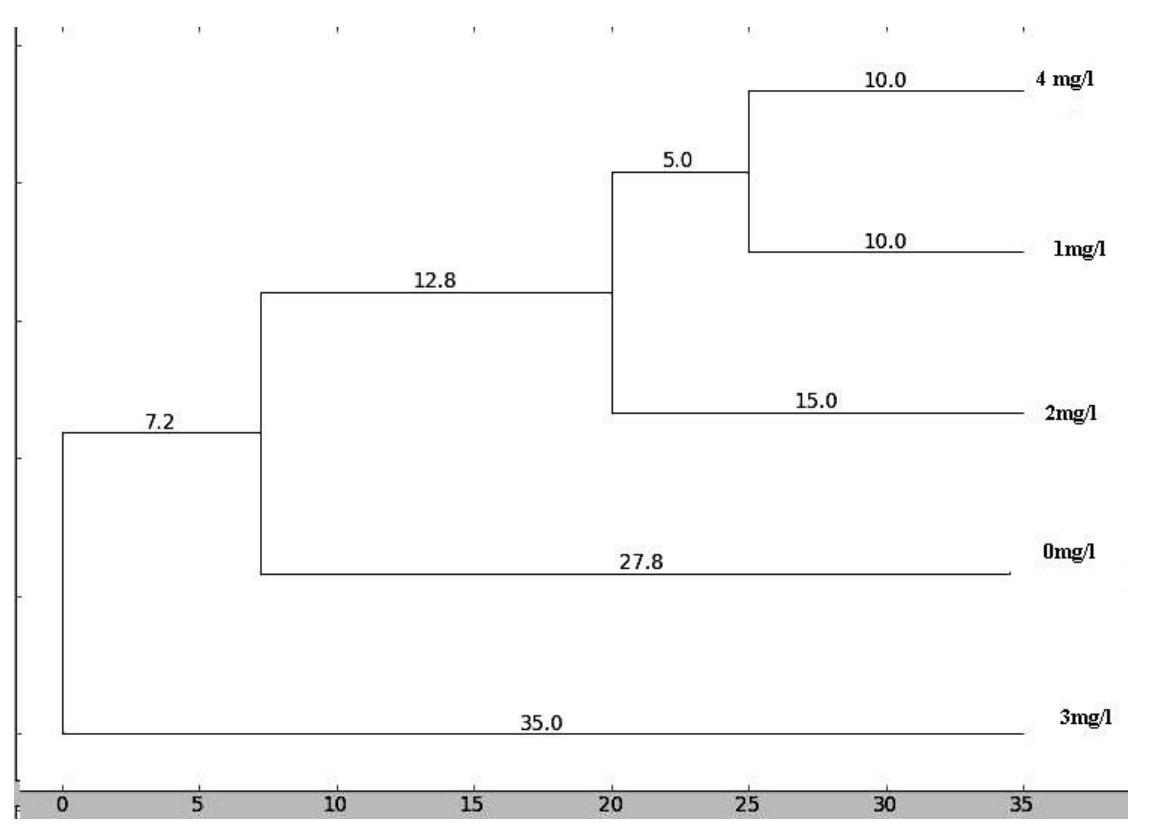

Fig.1. The phylogenetic tree of the five different concentrations of glufosinate ammonium at $0,1,2,3 \mathrm{and} 4 \mathrm{mg} / \mathrm{l}$ treated Jatropha curcas plant

\section{CONCLUSION}

The seeds of Jatropha curcas planted on MS gave the best results for successful seeds germinated on media at $3 \mathrm{mg} / 1$ of BA with $1 \mathrm{mg} / 1$ of IAA for shoot regeneration and then transferred to rooting media at 2 $\mathrm{mg} / 1$ of IBA and $2 \mathrm{mg} / 1$ of IAA. For obtaining the highest percentage of oil content from dried callus, medium at $0.5 \mathrm{mg} / \mathrm{l} \mathrm{BA}$ combined with $2 \mathrm{mg} / \mathrm{l} \mathrm{NAA}$ and $0.5 \mathrm{mg} / \mathrm{l} 2,4-\mathrm{D}$, for the induction of genetic variation glyphosinate ammonium to be added at $3 \mathrm{mg} / \mathrm{l}$.

\section{REFERENCE}

Achten, W. M. J., L. Verchot, Y.J. Franken, E. Mathijs, V.P. Singh, R. Aerts and B. Muys. 2008. Jatropha bio-diesel production and use. Biomass and Bio energy. 32 (12):1063-1084.

Baker, M.C. 1999. Improved sheet development and rooting from mature leaves and roots of Eryngium foetidum L., a food flavoring agent. Curr. Sci.75:644- 666.

Brody, J. R. and S. E. Kern. 2004. History and principles of conductive media for standard DNA electrophoresis. Analbiochem. 333:1-13.

Buchanan, B. , W. Gruissem and R. L. Jones 2000. Biochemistry and Molecular Biology of Plants. Book. pp 382.

Carpenter, D. and C.Boutin. 2010. Sublethal effects of the herbicide glufosinate ammonium on crops and wild plants: short-term effects compared to vegetative recovery and plant reproduction. Ecotoxicology. 19:1322-1336.
Cato, S. A. and T. E. Richardson. 1996. Inter- and intraspecific polymorphism at chloroplast SSR loci and the inheritance of plastids in Pinus radiata D. Don. Theoretical and Applied Genetics. 93: 587-592.

Cavas, T. and S. Konen. 2007. Detection of cytogenetic and DNA damage in peripheral erythrocytes of goldfish(Carassius auratus) exposed to a glyphosate formulation using the micronucleus test and the comet assay. Mutagenesis, 22 (4):263-268.

Dagar, J. C. , O.S. Tomar, Y. Kumar, H. Bhagwan, R.K. Yadev and K. Tyagi. 2006. Performance of some underexplored crops under saline irrigation in a semiarid climate in Northwest India, Land Degrad. Develop. 17: 285-299.

Dalton, A. J. 1955. A chrome-osmium fixative for electron microscopy. Anat. Rec. 121-281.

Deng, X., Z. Fang and Y. Liu. 2010. Ultrasonic transesterification of Jatropha curcas L. oil to biodiesel by a two-step process. Energy Conversion Management. 51: 2802-2807.

Dermen, H. and S.L. Emsweller. 1961. The Use of Colchicin In plant Breeding. Agricultural Research Service. pp 2434.

Dhar, U. and M. Joshi. 2005. Efficient plant regeneration protocol through callus For Saussurea obvallata (DC) Edgrew. (Astteraceae): effect of explants type, age and plant growth regulators. Plant Cell Rep. 24:195-200.

Dzialuk, A., M. Małgorzata, B. Krystyna, M. M. Jose, R. Angel and B. Adam. 2011. Population genetic structure of Juniperus phoenicea (Cupressaceae) in the western Mediterranean Basin:gradient of diversity on a broad geographical scale. Ann. For. Sci. 68 (8): 1341-1350. 
Emsweller, S.L. 1988. Developments in Plant Breeding Due to the Use of Colchicine. Lily Yearbook of the North American Lily Society. 41: 75-85.

Henning, R. K. 2010..Assessment of the impact of the dissemination of "the Jatropha System" on the ecology of the rural area and the social and economic situation of the rural population (target group) in selected countries in Africa. Jatropha curcas in Africa - an Evaluation Book. pp1-49.

Henning ,R.K. 2002. Using the Indigenous Knowledge of Jatropha: the use of Jatropha curcas oil as raw material and fuel . CAB Direct. (47) p4.

Joshi, M. and U. Dhar. 2003. In vitro propagation of Saussurea obvallate (DC) Edgew.- an endangered ethnoreligious medicinal herb of Himalaya.Plant Cell Rep. $21: 933-939$.

Kumar, N. and M.P. Reddy. 2012. Thidiazuron (TDZ) induced plant regeneration from cotyledonary petiole explants of elite genotypes of Jatropha curcas: a candidate biodiesel plant. Ind. Crop Prod. 39:62-68.

Kumar, R.V , Y. K. Tripathi , P. Shukla and S. Ahlawat. 2009. Genetic diversity and relationships among germplasm of Jatropha curcas $L$. revealed by RAPDs. Tree-Struct. Funct. 23:1075-1079.

Lacuesta, M. , A. Muñoz-Rueda , C. González-Murua and M.N. Sivak. 1992. Effect of phosphinothricin (glufosinate) on photosynthesis and chlorophyll emission by barley leaves illuminated under photorespiratory and nonmetabolism of glufosinate in five weed species as influenced by Nicotiana plumbaginifolia. Planta. 182 : 408-414.

Lea, P.J. and S.M. Ridley. 1989. Glutamine synthetase and its inhibition. In AD Dodge, ed, Herbicides and Plant Metabolism. Cambridge University Press, Cambridge, UK. pp 137-170.

Loberant, B. and A. Altman. 2010. Micropropagation of Plants. Encyclopedia of Industrial Biotechnology. 442:117.

Merkel, U., G.W Rathke, C. Schuster, K.Warnstorff and W. Diepenbrock. 2004. Use of glufosinate-ammonium to control cruciferous weed species in glufosinate-resistant Winter Oilseed Rape. 85 (2:3): 237-249.

Mukherjee, P., A.Varshney, T.S. Johnson and T.B. Jha. 2011. Jatropha curcas: a review on biotechnological status and challenges. Plant Biotechnol Rep. 5:197-215.

Murashige, T. and F.A. Skoog. 1962. A revised medium for rapid growth and bioassays with tobacco tissue culture. Physiol Plant. 1(5): 473-479.

Nahar, K. 2011. Cultivation of Jatropha curcas L. in Bangladesh: A Sustainable. Solution to the Energy, Environmental and Socioeconomic Crisis,Book. pp. 3-67.

Naji, D. A., H.J. Attiya and H.M. Askar. 2015. Effect of plant growth regulators(IBA,BA and CCC) On some vegetative characters of Lilium spp. L.). Iraqi J. of Sci .56(2) 972:982.
Nandagopal, S. and R.B.D. Kumari. 2007. Effectiveness of auxin induced in vitro root culture in chicory. J. Cent. Eur. Agric. (8): 73-80.

Nhut, D. T., N. T. D. Tam, V. Q. Luan, N. Q. Thien ,R.N. Kaur, Thakur and D.R. Sharma. 2006. Low cost strategy for micropropagation of Lilium Asiatic hybrid cv. Toscana. J. Hort. Sci. 1(1): 24- 27.

Pavel, A.B. and C.L.Vasile. 2012. PyElph - a software tool for gel images analysis and phylogenetics. BMC Bioinformatics. pp. 2-6.

Pline, W.A., J. Wu and K.K. Hatzios. 1999. Absorption, translocation, and metabolism of glufosinate in five weed species as influenced by ammonium sulphate and pelargonic acid. Weed Sci. 47: 636-643.

Rahdari, P., V. Sarifzadeh, F. Safarnejad, F. G. Poor and S. K. Aframjani. 2013. Effects of auxin and cytokinin on morphological and physiological factors in stem and root in Avene sativa L. Life Sci. J.10(1): 788-795.

Rank, J., A. G. Jensen , B. Skov, L. H. Pedersen and K. Jensen. 1993. Genotoxicity testing of the herbicide Roundup and its active ingredient glyphosate isopropylamine using the mouse bone marrow micronucleus test, Salmonella mutagenicity test, and Allium anaphase-telophase test. Mutat. Res. 300: 29-36.

Sahai, A. and A. Shahzad 2013. High frequency in vitro regeneration system for conservation of Coleus forsklohlii: a threatened medicinal herb. Acta Physiol Plant. (35) :473-481.

Sarah, A., M.D. Luse, and G. S. Margaret. 1957. Electron Microscopy of Salivary Gland Viruses. Departments of pathology and Anatomy, Washington University school of Medicine,St. Louis. pp. 623-632.

SAS Institute. 2002. SAS user guide and program 20 version 9.0.38. cary, NC27513.

Scott, T.k. 1972. Auxins and roots.Ann.Res., Plant physiol.23: 235-258.

Shrivastava, S. and M. Banerjee. 2009. Algal filtrate: a low cost substitute to synthetic growth regulators for direct organogenesis of embryo culture in Jatropha curcas (Ratanjyot). Acta Physiologiae Plantarum. 31(6):12051212.

Siimes, K., S. Ra“mo“ , L. Welling, U. Nikunen and P. Laitinen. 2006. Comparison of the behavior of three herbicides in a field experiment under bare soil conditions. Agri. Water Manage. 84:53-64.

Sivikova, K. and J. Dianovsky. 2006. Cytogenetic effect of technical glyphosate on cultivated bovine peripheral lymphocytes. Int. J. Hyg. Environ. Health. 209: 15-20.

Skora, N.F., H.D. Coble and F.T. Corbin. 2000. Absorption, translocation, and metabolism of 14C-glufosinate in Xanthium strumarium, Commelina diffusa, and Ipomoea purpurea. Weed Sci. 48: 171-175.

Snedecor, G. and W. Cochran. 1967. Statistical Methods. Sixth Edition. The Iowa State University Press. Ames, IA: The Iowa State University Press. 
Steel, R.G. and J.H. Torrie. 1980. Principles and Procedures of Statistics $2^{\text {nd }}$ ed. Mc Graw Hill Book company, New Tork ,N.Y.

Stfaan, p. 1994. Applied aspects of plant regeneration.IN:Dixon RA,Gonzales RA (eds) plant cell culture: a practical approach. Oxford.127-145.

Tukey, J.W. 1994. The Collected Works of John W. Tukey VIII. Multiple Comparisons 1948-1983. Chapman and Hall, New York. pp. 469.
VanTuyl, J.M., H.M.V. Holsteijn and A.A. Kwakkenbos. 1990. Research on polyploidy in interspecific hybridization of Lily. Acta Horticulturae. 266: 323-329.

Wendler, C., M. Barniske and A. Wild. 1990. Effect of phosphinothricin (glufosinate) on photosynthesis and photorespiration of C3 and C4 plants. Photosynth Res. 24: 55-61.

\section{الملخص العربي}

\section{إحداث الطفرات فى نبات الجاتروفا تحت الظروف المعمليه}

$$
\text { محمد جمال التركى , هاني محمد النجار , نادرأحمد الثنهورى, أميرة عبد الحميد يوسف }
$$

كيماوى وذلك بالتركيزات التالية| - r- r - ؟ مجم/لتر وذلك بنقع الجذور لمدة ساعتين وكانت أفضل بيئة زراعة المحتوية على BA عند r,rمجم/لتز و IAA عند ا مجم/لتز وعند نقل هذة المجاميع الخضرية النامية معمليا على تركيزات

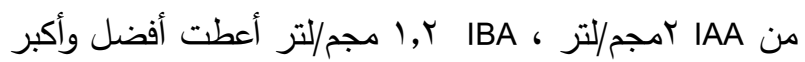

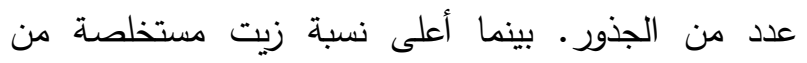

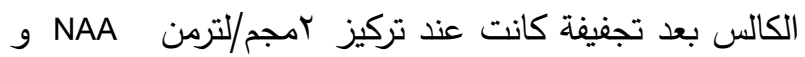
ه. •مجم /لتر من BA و ه. • مجم/لتر من D-D لم يكن للكولشسين بجميع تركيزاتة أى تأثيرعلى نباتات

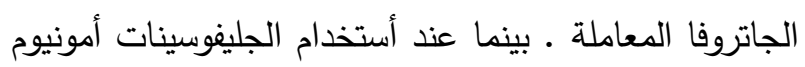
وجد أن لها تأثير وأحدثت أختلافات جينية بين النباتات المعاملة عند تركيز بوء مجم/لتر وأعلى نسبة اختلافات جينية كانت عند r مجم/لتر من الجليفوسينات.
أجريت هذة الدراسة فى معمل زراعة الأنسجة- قسم

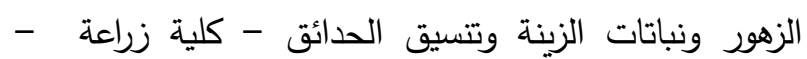

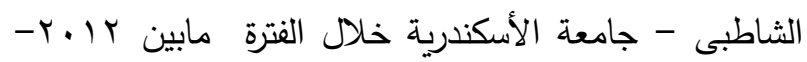
1 • ب لتطويروإيجاد بروتوكول فعال للإكثار المعملى الدقيق

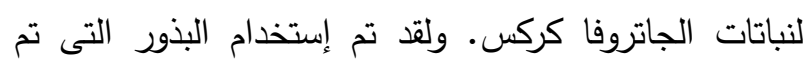
الحصول عليها من اشجار الجاتروفا من حدائق أنطونيادس خلال الدراسة المعمليه لأستحثاث أكثار (تضاعف) المجاميع الخضرية. تم زراعة البذور على بيئة MS مضاف إليها توليفات مختلفة من الأوكسين (IAA) . - 1 - r مجم/لتر

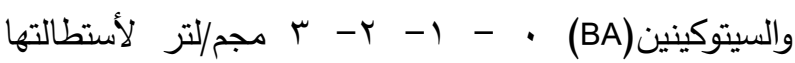

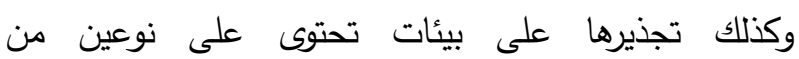

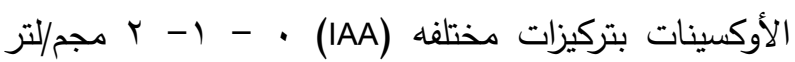

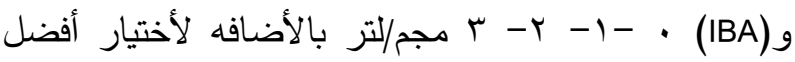
النباتات المكونة للجذور ومعاملتها بالكولشسين كمطفر 